\title{
Position in the distributional range and sensitivity to forest fragmentation in birds: a case history from the Atlantic forest, Brazil
}

\author{
LUIZ DOS ANJOS, ROBERT D. HOLT and SCOTT ROBINSON
}

\begin{abstract}
Summary
We tested the hypothesis that endemic bird species of the Brazilian Atlantic forest are more sensitive to forest fragmentation than non-endemics in a fragmented landscape in northern Paraná state of southern Brazil. Levels of sensitivity (high, medium, and low) were previously determined in the landscape based on the occurrences of bird species in 14 forest fragments. We evaluated 112 forest bird species and found that endemic species were more sensitive than non-endemics. Among the endemic species, highly sensitive species tended to have smaller geographic ranges. In a second analysis, we determined that birds at the edges of their geographic ranges in northern Paraná were more vulnerable to forest fragmentation. Combining both factors we found that endemic birds at the edge of their ranges were the most sensitive to fragmentation. Our results suggest that endemics and species at the edges of larger ranges might need larger tracts to ensure their continued existence within that region. Our results, however, also indicate that even small forest fragments may have considerable value for non-endemics and for species closer to the centres of their ranges.
\end{abstract}

\section{Resumo}

Nós testamos a hipótese de que espécies de aves endêmicas da floresta Atlântica brasileira são mais sensíveis à fragmentação florestal do que aquelas não endêmicas na paisagem fragmentada do norte do Estado do Paraná no sul do Brasil. Níveis de sensibilidade (alta, média e baixa) foram previamente determinados naquela paisagem baseados na ocorrência das espécies em 14 fragmentos florestais. Nós avaliamos 112 espécies de aves florestais e encontramos que espécies endêmicas são mais sensíveis que aquelas não endêmicas. Entre as espécies endêmicas, aquelas altamente sensíveis tenderam a ter menores distribuições geográficas. Em uma segunda análise nós determinamos que aves que estavam na borda de suas distribuições geográficas no norte do Paraná foram mais vulneráveis à fragmentação florestal. Combinando ambos os fatores nós encontramos que aves endêmicas na borda de suas distribuições foram as mais sensíveis à fragmentação. Nossos resultados sugerem que endêmicas e espécies na borda de suas maiores distribuições devem precisar de grandes áreas para assegurar suas contínuas existências dentro daquela região. Nossos resultados, entretanto, também indicam que mesmo pequenos fragmentos florestais podem ter considerável valor para não endêmicas e para espécies mais próximas do centro de suas distribuições.

\section{Introduction}

One potential conservation strategy is to select sites with a large number of species deemed at risk (e.g. Wege and Long 1995). There are many different ways one can assess 'risk' in a conservation 
context. Ideally, one would be able to conduct detailed studies of species' behaviours, life histories, trophic linkages and autecological requirements, and integrate such knowledge into population models that could be used for risk assessment. In many situations, such intensive studies have not been conducted, and there is no guarantee that they will be, at least over the short time-scale that is relevant for conservation planning and decision-making in the face of rapid environmental change and degradation. An alternative approach that may be useful is to place local conservation assessment into a broader geographical context (e.g. Pimm and Raven 2000, Harris and Pimm 2004, 2008).

The total number of endemic species found in a site has been used to select priority areas for conservation (Fishpool et al. 1998, Heath and Evans 2000). Indeed, this was one of the original criteria developed by BirdLife International over 20 years ago, in order to select priorities for conservation at a global scale. Areas with high numbers of endemic species with overlapping distributions are denoted by BirdLife International as Endemic Bird Areas (EBAs), sites within them being selected as potential Important Bird Areas (IBAs) for conservation. IBAs were recently selected for all the states of the Brazilian Atlantic forest (Bencke et al. 2006).

Vulnerability to fragmentation may also be affected by the position of a population within the geographical range of a species. Because populations at the edge of the range are generally smaller than those closer to the centre (Holt et al. 2005) and may have fewer nearby sources of colonists to rescue vacant patches, populations near the edges of their ranges may be more vulnerable to fragmentation (Lomolino and Channell 1995, 1998). Data from several taxa around the world (both animals and plants), however, do not always show a pattern of higher persistence of species near the centre of their ranges, although these analyses have occurred at a global rather than a local scale (Lomolino and Channell 1995, 1998; Channell and Lomolino 2000a). Thus, it is not clear whether at a local scale, species may be more or less susceptible to fragmentation at the edges of their ranges.

In this study we examined whether species endemic to the Atlantic forest and those with small geographic ranges are more vulnerable to forest fragmentation, a particularly severe problem in that biome (Torezan 2003), using previously published data from forest fragments scattered throughout northern Paraná state, southern Brazil (Anjos et al. 2004, Anjos 2006). We tested sensitivity to fragmentation in the endemic species, taking into account their estimated range sizes. We also determined whether species at the periphery of their ranges are more vulnerable to habitat fragmentation than are non-endemic species closer to the centre of their geographic ranges within the same, highly disturbed landscape.

\section{Methods}

\section{Study area and bird surveys}

The effects of forest fragmentation on birds in northern Paraná have been investigated for several years (Anjos 2001a,b, 2006, Anjos et al. 2004). In that landscape, where the matrix is composed mainly of agriculture and pasture, most remaining forest occurs in small, discrete patches. In a $50,000 \mathrm{~km}^{2}$ region around the city of Londrina, for example, there are only 17 forest fragments larger than 100 ha (Torezan 2003). Deforestation in this region mostly occurred in the last 60-70 years. The largest protected area among those fragments is Mata dos Godoy State Park (656 ha). In spite of this severe level of fragmentation, which is comparable to habitat loss documented in agricultural sections of the midwestern USA (Brawn and Robinson 1996), several Atlantic forest endemics persist, even in quite small and isolated fragments. Indeed, some endemic species actually occur in higher abundances in smaller than in larger fragments (Anjos 2001a), whereas others are found only in larger fragments or their abundances are significantly lower in smaller and isolated fragments (Anjos 2001a). Anjos (2006) used the data presented in Anjos et al. (2004) to assign bird species to three levels of sensitivity to fragmentation (high, medium, and low). The levels of sensitivity for each bird species were based on point censuses of abundance in Mata 
dos Godoy State Park and two other larger forest fragments, which were used as reference sites. Eleven other forest fragments were categorized according to size (large: $180-570$ ha or small: $<180 \mathrm{ha}$ ) and degree of isolation (not isolated: connected by a forest corridor to another large fragment or when the distance to a fragment of similar size was less than $800 \mathrm{~m}$; or isolated: $>2,000 \mathrm{~m}$ from any other fragment of similar size). Bird species were assigned to one of three levels of sensitivity to forest fragmentation: (I) high, when the species occurred only in the reference fragments and in large, non-isolated patches; (2) medium, when the species occurred in the reference tracts, large and non-isolated tracts, small and non-isolated tracts, and large, isolated tracts, and (3) low, when the species occurred in all fragments, even in those that were small and isolated (see Anjos 2006 for details). We eliminated from the bird list presented in Anjos (2006) a few species mostly found at forest edges as well as those that are known to occur in the matrix landscape (mostly agricultural areas and pastures); thus, we restricted the analyses presented here to 112 bird species that are fundamentally restricted to forests. A list of the bird species occurring in the forest fragments is given in the Supplementary materials.

\section{Data analysis}

We examined the number of species in each category of sensitivity in northern Paraná, contrasting Atlantic forest endemic versus non-endemic species. We used the list of endemic species presented in Bencke et al. (2006). In order to examine whether species at the edge of their ranges are more sensitive to forest fragmentation, we used the range maps based on del Hoyo et al. (1992-2006) and Ridgely and Tudor (1994) and for each species categorized whether northern Paraná is close to the known border of its range. We considered northern Paraná as the border of a species' range if it was within the outer 10\% of its distribution (Table 1 ).

Harris and Pimm (2008) estimated the original range of endemic bird species of Atlantic forest. We used those estimated values to evaluate if highly sensitive species were more likely to have smaller ranges than species with medium and low sensitivity. We recognize, however, that these are actually upper limits on current species' distributions, which can be a shrunken shadow of their former ranges (see Harris and Pimm 2008) given that the lowland Atlantic forest has been reduced to $c .4-6 \%$ of its original forest cover in the state of Paraná.

\section{Statistical analysis}

An $\mathrm{RxC}$ test for independence (G-test) was used to evaluate significance $(\alpha=0.05)$ between number of species in different categories of sensitivity (high, medium, and low) and range categories (range-restricted and not range-restricted; Table 1 ). We evaluated the differences among the medians of the endemic species ranges in those categories of sensitivity using MannWhitney $U$-tests $(\alpha=0.05)$.

Table 1 . Number of bird species classified into one of three categories of sensitivity to forest fragmentation in northern Paraná, Brazil, based on their endemism (endemic and non-endemic) and whether the fragmented studied landscape of northern Paraná was at the edge of their ranges or the interior.

\begin{tabular}{llrl}
\hline & & Sensitivity & Low \\
\cline { 2 - 4 } & High & Medium & \\
\hline Endemic & 8 & 4 & 2 \\
$\quad$ Edge of range & 8 & 15 & 13 \\
$\quad$ Interior of range & & 9 & 10 \\
Non-endemic & 5 & 10 & 25 \\
$\quad$ Edge of range & 3 & & \\
$\quad$ Interior of range & & & \\
\hline
\end{tabular}




\section{Results}

Our results show that endemic bird species were indeed more sensitive to forest fragmentation than non-endemics $(G=9.66, \mathrm{df}=2, P<0.1)$. The endemic species Bertoni's Antbird Drymophila rubricollis and Dusky-tailed Antbird D. malura, for example, had high sensitivity to forest fragmentation, whereas Variable Antshrike Thamnophilus caerulescens and Rufous-winged Antwren Herpsilochmus rufimarginatus, non-endemics, had low sensitivity (Appendix 1). Median range size was significantly smaller in species with high sensitivity to fragmentation than those with medium sensitivity $(U=0.007)$; none of the other comparisons were significant.

Species at the edges of their ranges were also more sensitive to forest fragmentation $(G=6.45$, $\mathrm{df}=2, P<0.05$, Table 1 ). The Black-necked Aracari Pteroglossus aracari, which is at the southern border of its range in northern Paraná, for example, was more sensitive to fragmentation than were Red-breasted Toucan Ramphastos dicolorus and Spot-billed Toucanet Selenidera maculirostris, both of which were found further south down to northern Rio Grande do Sul and Argentina (Supplementary materials).

Combining information on both endemism and position in their geographic range, we found evidence for an interaction effect. Endemic species at the periphery of their geographic ranges were much more susceptible than non-endemic or endemic species in their range interiors. (Table 2). There was also a small, but statistically significant, effect of endemism on sensitivity for interior species (Table 2). This may explain why Spot-breasted Antvireo Dysithamnus stictothorax (an endemic species at the border of its range) is highly sensitive to forest fragmentation whereas its congener, Plain Antvireo D. mentalis (non-endemic and not at the periphery of its range) has low sensitivity (see Appendix $S_{1}$, Supplementary materials).

\section{Discussion}

We found that both range size and position within geographic range were significantly associated with vulnerability to forest fragmentation in Atlantic forest bird species. There are several possible reasons for these results. First, species at the edge of their range may have fewer nearby populations available to provide the immigrants necessary to rescue patches once they have lost their local populations. Second, there is often a broad correlation between local abundance and the extent of a species' range (Gaston 2003). All else being equal, if endemic species have low average abundance, they may be more vulnerable to a reduction in the area of suitable habitat. Holt et al. (1997) proposed a model of the relationship between range size and local abundance; one of the biological assumptions in this model was that some species have lower maximal growth rates. All else being equal, this can lead to a positive range-abundance correlation. A reduced maximal growth rate would mean there is a smaller demographic margin for error to help a species cope with unfavourable changes in its environment.

Some bird species that showed high or medium sensitivity to forest fragmentation in northern Paraná may not be as sensitive in other regions of the Atlantic forest. Swallow-tailed Manakin Chiroxiphia caudata and Plain Parakeet Brotogeris tirica, for example, are apparently much less

Table 2. RxC test of independence ( $G$-test; $\alpha=0.05$ ) of species and various combinations of endemism (endemic and non-endemic) and position in the species' ranges.

\begin{tabular}{lcl}
\hline & G-test & Significant \\
\hline Endemic/interior vs Endemic/edge & 5.77 & No \\
Non-endemic/interior vs Non-endemic/edge & 4.01 & No \\
Endemic/interior vs Non-endemic/interior & 7.17 & Yes \\
Endemic/edge vs Non-endemic/edge & 5.83 & No \\
Endemic/edge vs Non-endemic/interior & 16.68 & Highly \\
\hline
\end{tabular}


sensitive to fragmentation closer to the centre of their ranges in São Paulo state than they are in Paraná (Uezu et al. 2005). Channell and Lomolino (200ob) predicted that local extinctions would first occur in peripheral populations and then proceed to more central populations. Our results generally support this prediction, as species seem more likely to become extinct in small patches near the periphery of their range.

Geographic variation in sensitivity to forest fragmentation may also be related to local habitat suitability. The Atlantic forest is not a homogenous biome. It is composed of several types of forest; perhaps the seasonal semi-deciduous forests of northern Paraná and the dense ombrophilous forests of eastern São Paulo differ in their overall suitability for species such as C. caudata which has significantly higher populations in the latter forest type than the former (Anjos et al., in prep.). Low populations have been suggested as a factor that should increase sensitivity of species to habitat fragmentation (reviewed in Henle et al. 2004).

Our results suggest that both endemics and those at the edge of larger ranges might need larger tracts to ensure their continued existence within that region. Paradoxically, managers seeking to prevent the loss of biodiversity from their political units (e.g., those trying to preserve total diversity in the state of Paraná) might need to spend more resources on maintaining populations of species that barely make it into their geographic regions. State wildlife biologists face this problem routinely; should they worry more about populations of widespread species that are only marginally present within their geographic area, or should they spend more of their resources on those species for which their region offers prime habitat near the centre of their range? Fortunately, larger reserves benefit both endemic species and those at the periphery of large ranges. Collectively, these results point to the great importance of continuing to preserve the largest tracts of habitat within a political unit.

Nevertheless, it is also noteworthy that there are at least two examples of endemic species in the study that were not especially vulnerable to fragmentation, some of which were actually more abundant than their wider-ranging congeners in small fragments. Surucua Trogon Trogon surrucura and Rufous-capped Spinetail Synallaxis ruficapilla, both restricted-range species (Bencke et al. 2006), tended to be more abundant in the study area and were more tolerant of forest fragmentation than were their wider-ranging congeners, Black-throated Trogon T. rufus and Grey-bellied Spinetail S. cinerascens. As predicted by Holt et al. (1997) there are some circumstances in which a positive range-abundance correlation is not observed at all. For such species, even smaller forest fragments may have considerable conservation value - especially if the species is able to use secondary/edge habitats in small patches where competitors and predators may be absent. Therefore, we should not ignore the value of preserving small fragments for the conservation of some endemic species such as Araucaria Tit-spinetail Leptasthenura setaria, which is strongly associated with forests found further south of the study area, but is locally abundant in some small patches (Anjos and Boçon 1999).

In general, however, endemic species near their range limits seem particularly sensitive to habitat fragmentation. It would be instructive to look at this association in a wider context, as for example the entire Atlantic forest. Moreover, studies of global extinction risk (Purvis et al. 200o) have identified range size as one broad correlate of such risk. Our results suggest that the relationship between range attributes and conservation risk scale down to local landscape levels.

\section{Acknowledgements}

Financial support for this study was obtained from CNPq (Brazilian Council for Development of Science and Technology) through the Mata Atlântica Program and research grants for the first author (305593/07-2 and 201476/07-0). We thank the Instituto Ambiental do Paraná (IAP, Brasil) for permission to conduct research in the Godoy State Park, and the owners of private lands where the forest fragments are located. We also thank the three reviewers and Mike Barfield, whose suggestions improved the final version the manuscript, and the University of Florida Foundation for its support. 


\section{References}

Anjos, L. dos (2001a) Bird communities in five Atlantic Forest fragments in southern Brazil. Ornitol. Neotrop. 12: 11-27.

Anjos, L. dos (2001b) Comunidades de aves florestais: Implicações na conservação. Pp. $17-37$ in J. L. B. Albuquerque, J. F. Cândido, Jr., F. C. Straube and A. L. Roos, eds. Ornitologia neotropical: da ciência às estratégias. Tubarão, Brazil: Unisul Press.

Anjos, L. dos (2006) Bird species sensitivity in a fragmented landscape of the Atlantic forest in southern Brazil. Biotropica 38: 229-234.

Anjos, L. dos and Boçon, R. (1999) Bird communities in natural forest patches in southern Brazil. Wilson Bull. 111: 397-414.

Anjos, L. dos, Zanette, L. and Lopes, E. V. (2004) Effects of fragmentation on bird guilds of the Atlantic forest in north Paraná, southern Brazil. Ornitol. Neotrop. 15 (suppl.): 137-144.

Bencke, G. A., Mauricio, G. N., Develey, P. F. and Goerck, J. M. (2006) Áreas importantes para a conservação das aves no Brasil: parte 1, estados do dominio da Mata Atlântica. São Paulo, Brazil: SAVE ed.

Brawn, J. D. and Robinson, S. K. (1996) Source-sink dynamics may complicate the analysis of long-term census data. Ecology 77: 3-11.

Channell, R. and Lomolino, M. V. (200oa) Dynamic biogeography and conservation of endangered species. Nature 403: 84-86.

Channell, R. and Lomolino, M. V. (20oob) Trajectories to extinctions: spatial dynamics of the contraction of geographical ranges. J. Biogeog. 27: 169-179.

Fishpool, L. D. C., Heath, M. F., Waliczky, Z., Wege, D. C. and Crosby, M. J. (1998) Important Bird Areas - criteria to selecting sites of global conservation significance. In N. J. Adams and H. Slotow, eds. Proc. 22 Int. Ornithol. Congr., Durban. Ostrich 69: 428.

Gaston, K. J. (2003) The structure and $d y$ namics of geographical ranges. Oxford, UK: Oxford University Press.

Harris, G. and Pimm, S. L. (2004) Bird species' tolerance of secondary forest habitats and its effects on extinction. Conserv. Biol. 18: 1607-1616.
Harris, G. and Pimm, S. L. (2008) Range size and extinction risk in forest birds. Conserv. Biol. 22: 163-171.

Heath, M. F. and Evans, M. I., eds. (200o) Important Bird Areas in Europe: Priority sites for conservation. Cambridge, UK: BirdLife International. BirdLife Conservation Series 8.

Henle, K., Davies, K. F., Kleyer, M., Margulis, C. and Settele, J. (2004) Predictors of species sensitivity to fragmentation. Biodiv. Conserv. 13: 207-251.

Holt, R. D., Lawton, J. H., Gaston, K. J. and Blackburn, T. M. (1997) On the relationship between range size and local abundance: back to basics. Oikos 78: 183-190.

Holt, R. D., Keitt, T. H., Lewis, M. A., Maurer, B. A. and Taper, M. L. (2005) Theoretical models of species' borders: single species approaches. Oikos 108: 18-27. del Hoyo, J., Elliot, A. and Sargatal, J., eds. (1992-2006) The handbook of the birds of the world. Vols. 1-11. Barcelona, Spain: Lynx Edicions.

Lomolino, M. V. and Channell, R. (1995) Splendid isolation: patterns of geographic range collapse in endangered mammals. J. Mammal. 76: 335-347.

Lomolino, M. V. and Channell, R. (1998) Range collapse, re-introductions, and biogeography guidelines for conservation. Conserv. Biol. 12: 481-484.

Pimm, S. L. and Raven, P. (2000) Extinction by numbers. Nature 403: 843-845.

Purvis, A., Gittleman, J. L., Cowlishaw, G. and Mace, G. M. (2000) Predicting extinction risk in declining species. Proc. R. Soc. Lond. B 267: 1947-1952.

Ridgely, R. S. and Tudor, G. (1994) The birds of South America. Vol. 2. Oxford, UK: Oxford University Press.

Torezan, J. M. D. (2003) Fragmentação florestal e prioridades para conservação da biodiversidade. PhD Dissertation, Universidade de São Paulo, Brazil.

Uezu, A., Metzger, J. P. and Vielliard, J. M. E. (2005) Effects of structural and functional connectivity and patch size on the abundance of seven Atlantic forest bird species. Biol. Conserv. 123: 507-519. 
Wege, D. C. and Long, A. J. (1995) Key areas for threatened birds in the Neotropics.
Cambridge, UK: BirdLife International. BirdLife Conservation Series 5 .

\section{LUIZ DOS ANJOS*}

Departamento de Biologia Animal e Vegetal, Universidade Estadual de Londrina, Caixa Postal 6001, 86051-97o Londrina, Paraná, Brasil

ROBERT D. HOLT

Department of Biology, University of Florida, 111 Bartram Hall, Gainesville, FL 32611-8525, USA

\section{SCOTT ROBINSON}

Florida Museum of Natural History, University of Florida, PO Box 11780o, Gainesville, FL 32611-7800, USA

*Author for correspondence. E-mail: llanjos@sercomtel.com.br

Received 6 January 2009; revision accepted 26 May 2009;

Published online 15 December 2009

Appendix 1. Bird species grouped according to endemism to the Atlantic forest and levels of sensitivity to forest fragmentation. ${ }^{*}$ indicates those species for which northern Paraná is near the edge of their ranges.

Endemic and high sensitivity: Tinamus solitarius; Brotogeris tirica*; Pionopsitta pileata; Triclaria malachitacea*; Pulsatrix koeniswaldiana; Pteroglossus bailloni; Campephilus robustus; Dysithamnus stictothorax*; Drymophila rubricollis*; Drymophila malura*; Terenura maculata; Hylopezus nattereri*; Campylorhamphus falcularius*; Hemitriccus obsoletus*; Hylophilus poicilotis; Euphonia pectoralis.

Non-endemic and high sensitivity: Micrastur semitorquatus*; Dromococcyx pavoninus*; Trogon rufus*; Nonnula rubecula*; Pteroglossus aracari*; Grallaria varia; Oxyruncus cristatus; Vireo olivaceus.

Endemic and medium sensitivity: Pyrrhura frontalis; Trogon surrucura; Baryphthengus ruficapillus; Ramphastos dicolorus; Selenidera maculirostris; Melanerpes flavifrons; Psilorhamphus guttatus*; Scytalopus indigoticus*; Dendrocincla turdina; Xiphorhynchus fuscus; Cranioleuca obsoleta*; Philydor lichtensteini; Mionectes rufiventris; Hemitriccus diops*; Chiroxiphia caudata; Schiffornis virescens; Turdus subalaris; Pyrrhocoma ruficeps; Saltator fuliginosus.

Non-endemic and medium sensitivity: Patagioenas speciosa*; Trogon viridis*; Dryocopus lineatus*; Chamaeza campanisona*; Sittasomus griseicapillus; Xiphocolaptes albicollis; Synallaxis cinerascens; Philydor rufum; Poecilotriccus plumbeiceps*; Colonia colonus; Sirystes sibilator; Tityra inquisitor*; Tityra cayana*; Pachyramphus validus; Cyanocorax chrysops; Pipraeidea melanonota; Dacnis cayna*; Cacicus haemorrhous*; Euphonia violacea.

Endemic and low sensitivity: Aramides saracura; Phaetornis eurynome; Picumnus temminckii*; Veniliornis spilogaster; Piculus aurulentus; Hypoedaleus guttatus; Mackenziaena severa; Pyriglena 
leucoptera; Conopophaga lineata; Synallaxis ruficapilla; Automolus leucophthalmus; Heliobletus contaminatus*; Myiornis auricularis; Tachyphonus coronatus; Basileuterus leucoblepharus.

Non-endemic and low sensitivity: Crypturellus obsoletus; Crypturellus parvirostris*; Penelope superciliaris; Herpetotheres cachinnans*; Leptotila rufaxilla*; Geotrygon montana*; Forpus xanthopterygius*; Pionus maximiliani; Piaya cayana*; Anthracothorax nigricollis*; Colaptes melanochloros; Thamnophilus caerulescens*; Dysithamnus mentalis; Herpsilochmus rufimarginatus; Dendrocolaptes platyrostris; Xenops rutilans; Leptopogon amaurocephalus; Todirostrum cinereum*; Myiopagis caniceps*; Phylloscartes ventralis; Lathrotriccus euleri; Myiodynastes maculatus; Empidonomus varius; Myiarchus swainsoni; Pachyramphus viridis; Pachyramphus castaneus; Pachyramphus polychopterus; Turdus albicollis; Trichothraupis melanops; Habia rubica; Hemithraupis guira; Saltator similis; Parula pitiayumi; Basileuterus culicivorus; Euphonia chlorotica. 